\title{
Pengaruh minat dan motivasi belajar terhadap hasil belajar matematika siswa kelas VIII SMP Negeri 11 Mataram
}

\author{
Yulinar Maulinda Dewi ${ }^{*}$, Ketut Sarjana ${ }^{2}$, Junaidi ${ }^{3}$, Syahrul \\ Azmi ${ }^{4}$
}

${ }^{1}$ Mahasiswa Pendidikan Matematika, FKIP, Universitas Mataram, Mataram
2,3,4 Pendidikan Matematika, FKIP, Universitas Mataram, Mataram

lindadewi38@gmail.com

Diterima: 20-09-2021; Direvisi: 26-09-2021; Dipublikasi: 30-09-2021

\begin{abstract}
In the 2013 curriculum teachers are required to use diverse learning strategies so that students' learning outcomes improve, but during the math learning process, students' attention is still lacking, and have no interest in the subject. The purpose of this research is to find out the influence of learning interest, and motivation on the results of learning mathematics subjects grade VIII SMP Negeri 11 Mataram Year Lesson 2020/2021. The research method used is the Questionnaire and Documentation Method, which is used to obtain data in accordance with respondents' opinions related to information about learning interests and learning motivation, as well as collecting UAS grades of grade VIII students of SMPN 11 Mataram odd semester of the $2020 / 2021$ school year, which is then processed with descriptive statistics and simple linear regression. The results showed that there is a significant influence on the interest of learning on the results of learning mathematics, There is a significant influence on the motivation of learning on the results of learning mathematics, and there is a significant influence on the interest and motivation of learning on the results of learning mathematics students grade VIII SMP Negeri 11 Mataram School Year 2020/2021.
\end{abstract}

Keywords: learning motivation; learning interests; learning outcomes

\begin{abstract}
Abstrak
Dalam kurikulum 2013 guru diharuskan menggunakan strategi pembelajaran yang beragam sehingga hasil belajar siswa meningkat, namun pada saat proses pembelajaran matematika berlangsung, perhatian siswa masih kurang, dan tidak mempunyai ketertarikan terhadap mata pelajaran, Tujuan penelitian ini adalah untuk mengetahui pengaruh minat belajar dan motivasi belajar terhadap hasil belajar Matematika kelas VIII SMP Negeri 11 Mataram Tahun Pelajaran 2020/2021. Jenis penelitian ini adalah ex-post facto sedangkan metode pengumpulan yang digunakan adalah angket dan dokumentasi untuk mendapatkan data yang sesuai dengan pendapat responden terkait informasi mengenai minat belajar dan motivasi belajar, serta mengumpulkan nilai UAS siswa kelas VIII SMPN 11 Mataram semester ganjil tahun pelajaran 2020/2021, yang kemudian di olah dengan statistic deskriptif dan regresi linear sederhana. Hasil penelitian menunjukan bahwa: 1) terdapat pengaruh yang signifikan antara minat belajar terhadap hasil belajar matematika, 2) terdapat pengaruh yang signifikan atas motivasi belajar terhadap hasil belajar matematika, dan 3) terdapat pengaruh yang antara signifikan minat dan motivasi belajar terhadap hasil belajar matematika siswa kelas VIII SMP Negeri 11 Mataram Tahun Pelajaran 2020/2021.
\end{abstract}

Kata Kunci: motivasi belajar; minat belajar; hasil belajar 


\section{PENDAHULUAN}

Kementrian Pendidikan dan Kebudayaan terus memperbarui kurikulum dengan harapan proses pembelajaran dalam pendidikan mencapai peningkatan. Salah satunya yaitu dengan menerapkan kurikulum 2013. Dalam kurikulum ini, peserta didik diharuskan untuk berfikir kritis yang diwujudkan dalam tindakan nyata dengan membangun kolaborasi antar pelaku pendidikan (guru, siswa, dan pengelola), sehingga proses pembelajaran dapat mendorong siswa untuk menjadi lebih aktif dan kreatif. Dalam kurikulum 2013 diharuskan menggunakan strategi pembelajaran yang beragam sehingga hasil belajar siswa meningkat (Kementerian Pendidikan dan Kebudayaan, 2014).

Pada kenyataannya, hasil belajar matematika di SMP Negeri 11 Mataram pada kelas VIII termasuk kurang maksimal karena masih banyak nilai siswa belum tuntas. Rendahnya hasil belajar matematika siswa di SMP Negeri 11 Mataram, secara lebih khusus dapat dilihat dari hasil rata-rata nilai Ulangan Tengah Semester (UTS) siswa kelas VIII SMPN 11 Mataram Tahun Pelajaran 2020/2021 pada tabel berikut:

Tabel 1. Hasil Nilai UlanganTengah Semester Ganjil Mata Pelajaran MatematikaSiswa Kelas VIIISMP Negeri11 Mataram Tahun Pelajaran 2020/2021

\begin{tabular}{ccccc}
\hline No. & Kelas & JumlahSiswa & $\begin{array}{c}\text { JumlahSiswa } \\
\text { yang Lulus }\end{array}$ & PresentaseKetuntasanKlasikal \\
\hline 1 & VIII A & 31 & 8 & $25,81 \%$ \\
2 & VIII B & 32 & 11 & $34,37 \%$ \\
3 & VIII C & 32 & 9 & $28,12 \%$ \\
4 & VIII D & 31 & 7 & $22,58 \%$ \\
\hline
\end{tabular}

Sumber: Guru Mata Pelajaran Matematika Kelas VIII SMP Negeri 11 Mataram

Berdasarkan hasil wawancara di SMP Negeri 11 Mataram dengan guru kelas VIII diketahui bahwa siswa SMP Negeri 11 Mataram memiliki motivasi belajar yang berbeda-beda. Kondisi tersebut disebabkan oleh berbagai hal, diantaranya yaitu: 1) siswa tidak terlalu menyukai pelajaran matematika karena menganggap bahwa matematika adalah mata pelajaran yang sulit dimengerti, 2) siswa belajar jika hanya akan ada ulangan saja, 3) siswa mengerjakan pekerjaan rumah (PR) di sekolah dan bahkan ada yang tidak mengerjakan sama sekali, tentunya hal ini menunjukkan kurangnya motivasi belajar siswa.

Disisi lain, berdasarkan hasil observasi ditemukan fakta bahwa pada saat proses pembelajaran matematika berlangsung, perhatian siswa masih kurang. Hal ini ditunjukkan pada saat guru menjelaskan materi, siswa kurang memperhatikan penjelasan yang disampaikan oleh guru. Banyak siswa yang asik ngobrol dengan teman sebangku, serta tiduran dengan meletakkan kepala di atas meja. Keaktifan siswa saat proses pembelajaran masih rendah. Hal ini ditunjukkan pada saat guru mengajukan pertanyaan, hanya beberapa siswa yang dapat menjawab pertanyaan yang diberikan oleh guru. Begitu juga saat guru memberikan kesempatan siswa untuk bertanya, tidak ada siswa yang mengajukan pertanyaan berkaitan dengan materi pelajaran 
matematika yang disampaikan oleh guru. Dari gejala yang ada merupakan indikator dari rendahnya perhatian siswa selama proses pembelajaran. Jadi rendahnya prestasi belajar seperti diungkap di atas ada hubungannya dengan hasil observasi dan hasil wawancara yang telah dilakukan. Slameto (2003) menyatakan, "minat belajar memiliki pengaruh yang besar terhadap hasil belajar, karena jika bahan pelajaran yang dipelajari tidak sesuai dengan minat siswa, siswa tidak akan belajar dengan baik. Jika belajar tanpa disertai minat, siswa akan malas dan tidak akan mendapatkan kepuasan dalam mengikuti pembelajaran".

Penelitian yang telah dilakukan oleh Zamsir menyimpulkan bahwa motivasi belajar berpengaruh positif dan signifikan terhadap hasil belajar siswa SMPN 1 Lawa. Disisi lain Sadirman (2011) menyatakan bahwa siswa tidak mempunyai ketertarikan terhadap suatu mata pelajaran menjadi penyebab siswa tidak memperhatikan apa yang disampaikan oleh guru termasuk kurangnya partisipasi siswa dalam mengemukakan pendapat pada saat proses belajar mengajar. Hal ini menjadi salah satu pertanda bahwa siswa tidak memiliki minat untuk belajar. Untuk menumbuhkan minat dalam belajar pada setiap pembelajaran sangat penting, terlebih dalam pelaksanaan pembelajaran matematika yang bagi sebagian siswa kurang diminati. Minat belajar dapat diartikan sebagai keinginan dari seseorang peserta didik pada suatu mata pelajaran sehingga membuat dirinya rajin mengikuti proses pembelajaran pada mata pelajaran tersebut yang pada akhirnya dapat membuat siswa berprestasi pada mata pelajaran tersebut.

Prestasi belajar dalam pelajaran matematika dapat dipahami sebagai suatu hasil belajar yang telah dicapai dari aktivitas belajar yang menghasilkan perubahanperubahan dalam bentuk pengetahuan, pemahaman dan keterampilan. Minat dan motivasi belajar mempunyai peranan penting dalam mencapai suatu keberhasilan dalam belajar, maka diharapkan siswa yang memiliki minat dan motivasi belajar yang rendah dapat menyadari bahwa hal tersebut masih bisa diperbaiki dan diatasi dengan berbagai usaha sehingga akan tercipta suasana belajar yang kondusif sehingga hasil belajar yang didapat akan maksimal.

Berdasarkan paparan latar belakang diatas, maka peneliti tertarik untuk melakukan penelitian dengan judul: "Pengaruh Minat dan Motivasi Belajar Terhadap Hasil Belajar Matematika Siswa Kelas VIII SMP Negeri 11 Mataram Tahun Pelajaran 2020/2021”.

\section{METODE PENELITIAN}

Penelitian ini adalah penelitian ex-post facto. Populasi dalam penelitian ini adalah seluruh siswa kelas VIII SMPN 11 Mataram tahun pelajaran 2020/2021 berjumlah 126 siswa yang tersebar dalam 4 kelas yaitu kelas VIII-A dengan 31 siswa, VIII-B dengan 32 siswa, VIII-C dengan 32 siswa, dan VIII-D dengan 31 siswa. Sedangkan, sampel daam penelitian ini adalah 56 siswa yang tersebar dalam 4 kelas. 
Data dalam penelitian ini dikumpulkan menggunakan metode angket dan dokumentasi. Instrumen yang digunakan yaitu angket tertutup menggunakan skala model likert yang sudah dmodifikasi. Skala likert mendasarkan pada empat poin yang rentangannya secara interval yaitu, Sangat Tidak Setuju (STS), Sangat Setuju (SS), Setuju (S), dan Tidak Setuju (TS).

Tabel 3.2 Skala Angket

\begin{tabular}{cccc}
\hline No & MinatBelajar $\left(X_{1}\right)$ & MotivasiBelajar $\left(X_{2}\right)$ & SkorUntukPernyataan \\
\hline 1 & Sangat Tidak & Sangat Tidak & 4 \\
2 & Setuju (STS) & Setuju (STS) & 3 \\
3 & Sangat Setuju (SS) & Sangat Setuju (SS) & 2 \\
4 & Setuju (S) & Setuju (S) & 1 \\
\hline
\end{tabular}

Data yang terkumpul kemudian dianalisis menggunakan statistic deskriptif untuk mengetahui bagaimana minat dan motivasi belajar dan untuk mengetahui hasil belajar mata pelajaran matematika kelas VIII SMP Negeri 11 Mataram dengan terlebih dahulu dilakukan uji prasyarat (uji normalitas,uji linieritas,uji multikolinieritas). Selanjutnya dilakukan uji korelasi pearson product moment, korelasi berganda, regresi linier sederhana dan berganda (Siregar, 2012).

\section{HASIL DAN PEMBAHASAN}

\subsection{Hasil Pengujian Hipotesis}

Uji t (Uji Parsial)

Uji t dapat diketahui denga melihat nilai signifikansi pada tabel coefficients. Hasil uji t adalah sebagai berikut:

Tabel 2. Hasil Uji t Minat BelajarTerhadap Hasil BelajarMatematika

\begin{tabular}{|c|c|c|c|c|c|c|}
\hline & \multirow[t]{2}{*}{ Model } & \multicolumn{2}{|c|}{$\begin{array}{l}\text { Unstandardized } \\
\text { Coefficients }\end{array}$} & \multirow{2}{*}{$\begin{array}{c}\text { Standardized } \\
\text { Coefficients } \\
\text { Beta }\end{array}$} & \multirow[t]{2}{*}{$\mathrm{t}$} & \multirow[t]{2}{*}{ Sig. } \\
\hline & & $\mathrm{B}$ & Std. Error & & & \\
\hline \multirow[t]{2}{*}{1} & (Constant) & $\begin{array}{r}31,16 \\
5\end{array}$ & 5,639 & & 5,526 &, 000 \\
\hline & Minat_Belajar &, 552 &, 107 &, 576 & 5,176 &, 000 \\
\hline
\end{tabular}

a. Dependent Variable: Hasil_Belajar

Tabel 2 menunjukkan bahwa nilai signifikansi variabel minat belajar sebesar $0,000<$ nilai signifikan $(0,05)$ sehingga dapat disimpulkan bahwa minat belajar berpengaruh terhadap hasil belajar matematika siswa kelas VIII di SMP Negeri 11 Mataram. 
Tabel 3. Hasil Uji t Motivasi Belajar Terhadap Hasil Belajar Matematika

\begin{tabular}{|c|c|c|c|c|c|c|}
\hline & \multirow{2}{*}{ Model } & \multicolumn{2}{|c|}{$\begin{array}{l}\text { Unstandardized } \\
\text { Coefficients }\end{array}$} & \multirow{2}{*}{$\begin{array}{c}\begin{array}{c}\text { Standardized } \\
\text { Coefficients }\end{array} \\
\text { Beta }\end{array}$} & \multirow{2}{*}{$\mathrm{t}$} & \multirow{2}{*}{ Sig. } \\
\hline & & B & $\begin{array}{l}\text { Std. } \\
\text { Error }\end{array}$ & & & \\
\hline & (Constant) & 25,174 & 5,521 & & 4,559 & ,000 \\
\hline 1 & Motivasi_Belajar & ,672 & 105 & ,655 & 6,375 & ,000 \\
\hline
\end{tabular}

Berdasarkan hasil perhitungan yang ditunjukkan pada tabel 4.21 menunjukkan bahwa nilai signifikansi variabel motivasi belajar sebesar $0,000<$ nilai signifikan $(0,05)$ sehingga dapat disimpulkan bahwa motivasi belajar berpengaruh terhadap hasil belajar matematika siswa kelas VIII di SMP Negeri 11 Mataram.

Uji F (Uji Simultan)

Hasil uji $\mathrm{F}$ adalah sebagai berikut:

Tabel 4. Hasil Uji F Minat dan Motivasi Belajar Terhadap Hasil Belajar Matematika

ANOVAa $^{a}$

\begin{tabular}{|c|c|c|c|c|c|c|}
\hline \multicolumn{2}{|c|}{ Model } & \multirow{2}{*}{$\begin{array}{c}\begin{array}{c}\text { Sum of } \\
\text { Squares }\end{array} \\
1638,083\end{array}$} & \multirow{2}{*}{$\begin{array}{l}\text { df } \\
2\end{array}$} & \multirow{2}{*}{$\begin{array}{l}\begin{array}{l}\text { Mean } \\
\text { Square }\end{array} \\
819,041\end{array}$} & \multirow{2}{*}{$\begin{array}{c}\mathrm{F} \\
54,860\end{array}$} & \multirow{2}{*}{$\begin{array}{l}\text { Sig. } \\
, 000^{\mathrm{b}}\end{array}$} \\
\hline \multirow{3}{*}{1} & Regression & & & & & \\
\hline & Residual & 791,275 & 53 & 14,930 & & \\
\hline & Total & 2429,357 & 55 & & & \\
\hline
\end{tabular}

a. Dependent Variable: Hasil_Belajar

b. Predictors: (Constant), Motivasi_Belajar, Minat_Belajar

Berdasarkan perhitungan uji $\mathrm{F}$ pada tabel 4 didapat nilai sig sebesar $0.000<$ nilai signifikan 0,05, maka hipotesis dapat diterima. Dalam hal ini dapat dikatakan bahwa minat belajar dan motivasi belajar secara bersama-sama berpengaruh terhadap hasil belajar, sehingga kedua variabel independen (minat dan motivasi belajar) tersebut dapat digunakan untuk memprediksi variabel dependen (hasil belajar matematika).

\subsection{Pembahasan}

Penelitian ini bertujuan untuk mengetahui apakah ada pengaruh yang signifikan minat belajar dan motivasi belajar terhadap hasil belajar siswa pada mata pelajaran matematika kelas VIII SMP Negeri 11 Mataram Tahun Pelajaran 2020/2021 dengan sampel penelitian sebanyak 56 siswa. Dalam penelitian ini, peneliti menggunakan instrumen angket dan dokumentasi. Sebelum melakukan pengambilan data, peneliti menguji validitas instrumen angket kepada validator ahli. Kemudian, peneliti melakukan perbaikan instrumen angket yang telah divalidasi ahli, yang selanjutnya dilakukan uji validitas empiris. 
Hasil analisis statistik deskriptif minat belajar menunjukkan minat belajar siswa SMP Negeri 11 Mataram kelas VIII termasuk dalam kategori sedang dengan rata-rata skor sebesar 52,43 dimana skor minimum (terendah) sebesar 35 dan skor maksimum (tertinggi) sebesar 66. Hal ini disebabkan oleh kurangnya minat belajar siswa, hal ini terlihat dari siswa jarang mengulang kembali pelajaran yang telah diperoleh dari sekolah, hanya mengerjakan soal matematika jika ada tugas dan mengharapkan bantuan teman dalam mengerjakan tugas.

Selanjutnya, hasil analisis korelasi parsial menunjukkan terdapat hubungan yang positif antara minat belajar terhadap hasil belajar matematika. Hal tersebut ditunjukkan dengan nilai koefisien korelasi yang positif yaitu sebesar 0,576. Nilai koefisien yang positif menunjukkan bahwa semakin tinggi minat belajar matematika siswa maka semakin tinggi pula hasil belajar siswa. Sebaliknya, semakin rendah minat belajar siswa maka semakin rendah pula hasil belajar siswa yang akan diperoleh. Selanjutnya, berdasarkan uji t diperoleh $t_{\text {hitung }}$ sebesar 5,176 atau nilai sig sebesar 0,000 dimana nilai sig tersebut $<0,05$, sehingga dapat disimpulkan ada pengaruh yang signifikan minat belajar terhadap hasil belajar matematika siswa kelas VIII SMP Negeri 11 Mataram Tahun Pelajaran 2020/2021. Persamaan garis regresinya yaitu $Y=31,165+0,552 X$ dengan besar pengaruh minat belajar terhadap hasil belajar matematika pada siswa kelas VIII SMP Negeri 11 Mataram Tahun Pelajaran 2020/2021 yaitu sebesar $33,2 \%$.

Meskipun besar kontribusi yang diberikan minat belajar terhadap hasil belajar matematika termasuk dalam kategori sedang, namun minat belajar tetap memberikan pengaruh yang signifikan terhadap hasil belajar matematika. Hal ini ditunjukkan dengan perhatian dan ketertarikan siswa terhadap pelajaran matematika. Siswa yang selalu memperhatikan dalam proses pembelajaran memiliki minat belajar yang tinggi karena siswa tersebut mampu mengikuti pelajaran dengan baik. Minat belajar yang dimilikinya dapat meningkatkan hasil belajar siswa. Namun pada pernyataan mengulangi materi pelajaran matematika dirumah siswa masih belum optimal sehingga minat yang dimiliki siswa masih kurang. Penelitian ini sejalan dengan penelitian yang dilakukan Pangestu .

Selanjutnya, hasil analisis statistik deskriptif motivasi belajar menunjukkan motivasi belajar siswa termasuk dalam kategori sedang dengan rata-rata skor sebesar 51,95 dimana skor minimum (terendah) sebesar 38 dan skor maximum (tertinggi) sebesar 67 . Hal ini disebabkan oleh kurangnya motivasi belajar siswa, hal ini terlihat dari kurangnya keberanian siswa untuk bertanya kepada guru jika ada materi yang belum dimengerti, siswa lebih sering atau berani bertanya kepada teman-temannya daripada bertanya kepada guru.

Selanjutnya, hasil analisis korelasi parsial antara motivasi belajar terhadap hasil belajar matematika siswa menunjukkan adanya hubungan yang positif. Hal tersebut ditunjukkan dengan nilai koefisien korelasi yang positif yaitu sebesar 0,655. 
Berdasarkan uji t diperoleh $t_{\text {hitung }}$ sebesar 6,375 atau nilai sig sebesar 0,000 dimana nilai sig tersebut $<0,05$, sehingga dapat disimpulkan ada pengaruh yang signifikan minat belajar terhadap hasil belajar matematika pada siswa kelas VIII SMP Negeri 11 Mataram Tahun Pelajaran 2020/2021. Persamaan garis regresinya yaitu $Y=25,174+$ $0,672 X$ dimana nilai koefisien determinasi yang menunjukkan besarnya pengaruh motivasi belajar terhadap hasil belajar matematika pada siswa kelas VIII SMP Negeri 11 Mataram Tahun Pelajaran 2020/2021 yaitu sebesar 42,9\%.

Meskipun pengaruh yang diberikan motivasi belajar terhadap hasil belajar matematika hanya $42,9 \%$ namun motivasi belajar tetap memberikan pengaruh yang signifikan terhadap hasil belajar matematika. Hal ini ditunjukkan dengan tekun menghadapi tugas. Motivasi belajar yang tinggi tercermin dari ketekunan siswa yang tidah mudah putus semangat untuk mencapai keberhasilan meskipun dihadapi oleh berbagai kesulitan dalam belajar. Motivasi belajar dapat menggiatkan aktivitas belajar siswa. Siswa yang memiliki motivasi belajar yang tinggi akan melaksanakan kegiatan belajarnya dengan penuh semangat. Dengan demikian siswa tersebut akan mempunyai peluang lebih besar untuk memperoleh hasil belajar yang lebih baik dibandingkan dengan siswa yang memiliki motivasi belajar rendah. Adanya motivasi belajar yang tinggi terhadap suatu pelajaran akan menimbulkan semangat belajar dan ketertarikan yang besar untuk mempelajarinya secara sungguh-sungguh sehingga mencapai hasil yang diharapkan. Penelitian ini sejalan dengan penelitian yang dilakukan oleh Keban et al. (2018) yang menunjukkan terdapat pengaruh yang positif dan signifikan motivasi belajar terhadap hasil belajar matematika.

Hasil analisis statistik deskriptif hasil belajar matematika menunjukkan hasil belajar siswa termasuk dalam kategori sedang dengan rata-rata skor yaitu 60,11 dimana dimana skor minimum (terendah) sebesar 44 dan skor maksimum (tertinggi) sebesar 76. Kemudian, hasil analisis korelasi berganda menunjukkan adanya hubungan yang positif antara minat belajar dan motivasi belajar secara bersama-sama terhadap hasil belajar matematika siswa. Hal tersebut ditunjukkan dengan nilai koefisien korelasi yang positif yaitu sebesar 0,821. Selanjutnya berdasarkan uji F diperoleh $F_{\text {hitung }}$ sebesar 54,860 atau nilai sig sebesar 0,000 dimana nilai sig < 0,05, sehingga dapat disimpulkan ada pengaruh yang signifikan minat belajar dan motivasi belajar secara bersama-sama terhadap hasil belajar matematika siswa kelas VIII SMP Negeri 11 Mataram Tahun Pelajaran 2020/2021. Persamaan regresinya yaitu $Y=3,553+$ $0,478 x_{1}+0,606 x_{2}$ dengan besarnya pengaruh yang diberikan minat dan motivasi belajar terhadap hasil belajar matematika siswa kelas VIII SMP Negeri 11 Mataram Tahun Pelajaran 2020/2021 yaitu sebesar $66,2 \%$.

Meskipun kontribusi yang diberikan sebesar 66,2\% siswa yang memiliki perhatian dan ketertarikan serta ketekunan belajar akan memberikan dampak yang signifikan terhadap hasil belajar matematika siswa. Minat dan motivasi belajar merupakan salah satu faktor yang mempengaruhi hasil belajar, disamping faktor-faktor lain intelegensi, sikap, bakat dan lain-lain (Slameto, 2010)Hasil penelitian tersebut sejalan dengan hasil 
penelitian Heriyati (2017) yang menunjukkan terdapat pengaruh positif dan signifikan minat belajar dan motivasi belajar siswa secara bersama-sama terhadap hasil belajar.

Berdasarkan uraian di atas, secara teoritis maupun empiris dapat disimpulkan bahwa terdapat pengaruh minat belajar dan motivasi belajar terhadap hasil belajar matematika siswa kelas VIII SMP Negeri 11 Mataram Tahun Pelajaran 2020/2021.

\section{SIMPULAN}

Berdasarkan hasil penelitian, maka dapat ditarik kesimpulan sebagai berikut:

a. Minat belajar berpengaruh signifikan terhadap hasil belajar matematika siswa kelas VIII SMP Negeri 11 Mataram Tahun Pelajaran 2020/2021 dengan nilai koefisien korelasi sebesar 0,576 dan t_hitung sebesar 5,176 dimana persamaan garis regresinya yaitu $Y=31,165+0,552 X$, serta kontribusi yang diberikan sebesar $33,2 \%$.

b. Motivasi belajar berpengaruh signifikan terhadap hasil belajar matematika siswa kelas VIII SMP Negeri 11 Mataram Tahun Pelajaran 2020/2021 dengan nilai koefisien korelasi sebesar 0,655 dan t_hitung sebesar 6,375 dimana persamaan garis regresinya yaitu $\mathrm{Y}=25,174+0,672 \mathrm{X}$, serta kontribusi yang diberikan sebesar $42,9 \%$

c. Minat $\left(X_{1}\right)$ dan motivasi belajar $\left(X_{2}\right)$ berpengaruh signifikan terhadap hasil belajar matematika $(Y)$ siswa kelas VIII SMP Negeri 11 Mataram Tahun Pelajaran 2020/2021 dengan nilai koefisien korelasi sebesar 0,821 dan F_hitung sebesar 54,860 dimana persamaan garis regresinya yaitu $Y=3,553+0,478 X_{1}+0,606 X_{2}$, serta kontribusi yang diberikan sebesar $66,2 \%$.

\section{REKOMENDASI}

Guru sebaiknya menjadikan hasil penelitian ini sebagai bahan pertimbangan dalam menangani permasalahan-permasalahan belajar siswa utamanya hasil belajar, agar hasil belajar siswa dapat meningkat. Dilihat dari hasil penelitian, penelitian ini memberikan informasi bahwa minat dan motivasi belajar memberikan kontribusi terhadap hasil belajar sebesar $66,2 \%$. Hal ini menunjukkan masih banyak faktor lain yang mempengaruhi hasil belajar matematika, oleh karena itu dalam penelitian selanjutnya untuk mengetahui faktor-faktor yang mempengaruhi hasil belajar matematika selain minat dan motivasi belajar.

\section{REFERENSI}

Heriyati, H. (2017). Pengaruh Minat dan Motivasi Belajar Terhadap Prestasi Belajar Matematika. Formatif: Jurnal Ilmiah Pendidikan MIPA, 7(1), 22-32. https://doi.org/10.30998/formatif.v7i1.1383

Keban, M. L., Nahak, S., \& Kelen, Y. P. K. (2018). Pengaruh Motivasi Belajar Terhadap Hasil Belajar Matematika Siswa SMP. Jurnal Saintek Lahan Kering, 1(1), 20-21. https://doi.org/10.32938/slk.v1i1.440 
Dewi, dkk Pengaruh minat dan motivasi ...

Konsep dan Implementasi Kurikulum 2013, (2014). https://www.kemdikbud.go.id/kemdikbud/ dokumen/Paparan/Paparan Wamendik.pdf

Sadirman. (2011). Interaksi dan Motivasi Belajar Mengajar. Raja Grafindo Persada.

Siregar, S. (2012). Statistik Parametrik untuk Penelitian Kuantitatif. Bumi Aksara.

Slameto. (2003). Belajar dan Faktor-Faktor yang Mempengaruhinya. Rineka Cipta.

Slameto. (2010). Belajar dan Faktor-faktor yang Mempengaruhinya. Rineka Cipta. 